\title{
研究解説比
}

\section{絹繊維を強化材とする 熱可塑性複合材料の射出成形}

香 取 重 尊*, 木 村 照 夫**

\section{1. はじめに}

循環型社会の構築のため環境対応型素材の開発に大き な関心が寄せられている. 特に最近では自然環境中で容 易に分解され, 焼却しても有毒ガスの発生が少ない生分 解性樹脂が注目され, 大手メーカーが量産を目的に本格 的に生産に取り組むなど, 環境対応型素材の開発に一層 拍車がかかっている. 複合材料の分野ではこれまで強化 繊維として用いられてきたガラス繊維や炭素繊維に代わ り, 天然繊維を用いて補強する天然繊維強化複合材料に 強い関心が寄せられている．特に欧州の大手自動車メー カーで積極的に用いられたことをきっかけに，我が国に おいてもすでにいくつかの車種でケナフなどの植物繊維 を用いた複合材料が実用化されている．また，最近では ノート型パソコンの部品として用いる動きもあり, 天然 繊維複合材料は工業的に重要な位置にある. しかし，そ の性能は必ずしも十分なものではなく, 通常用いられる 麻などのセルロース繊維は親水性が高く母材との接着性 が悪い. また, 高い吸湿性を示すなど多くの課題が残さ れている.

天然繊維の中にはセルロース繊維の他にタンパク質か らなるものもあり, ウールやシルクなどがこれに相当す る.タンパク質は幾種類ものアミノ酸のポリペプチドで あり，それぞれのアミノ酸の側鎖は多様である．特に繊 維表面の化学的組成は複合材料に用いた際, 母材との接 着性に大きな影響を与えるが, 側鎖の中には踈水性の官 能基も多く含まれ, 糖を主成分とするセルロースとは異 なる界面接着性を示すことが予測される. また, 力学的 性質や耐熱性などもセルロース繊維とタンパク質繊維で は大きく異なる.このため, 場合によってはセルロース 繊維複合材料の欠点を補うような材料が得られることも 期待できる.

本研究ではタンパク質繊維のなかでも特にシルクに注
目している。シルクは繊維部分の結晶性（結晶化度, 配 向性など）が良く，力学的性質にも優れている。 また, 天然繊維の中では稀な連続繊維であり, フィラメントの 長さは数百メートルにも及ぶ.このため, 工業的に用い た際，目的に応じて繊維長を自在に変化させることが可 能である. 特に繊維分散系の複合材料では強化繊維の長 さは材料特性に大きな影響を与えるため, シルクのこの ような性質は材料設計の上で大きな利点となり得る.

本研究では環境への負荷を考慮した天然瀻維複合材料 の開発のひとつとして，これまで強化繊維としてほとん ど検討されていなかったタンパク質繊維に注目し，特に 絹纎維の複合材料強化材としての可能性を検討するとと もに，絹複合材料の特性を従来のガラス繊維複合材料と 比較検討し，新たな天然繊維複合材料の創生を試みる.

\section{2. 複合材料強化材としての絹繊維の 特性}

一般的に複合材料の強化材にはいくつかの性質が求め られる.母材よりも高い強度や弾性率が要求されること はいうまでもないが, 母材との接着性, 成形のしやすさ, また天然繊維の場合は特に成形工程中に受ける熱負荷に よる劣化があるため耐熱性などが求められる.

絹繊維は良く知られているようにセリシンとフィブロ インの 2 種類のタンパク質から構成され，2本のフィブ ロインの周りをセリシンが取り巻く構造をとっている. 通常アパレルなどには精練の工程を経てセリシンを除去 し, 風合いを良くしたものが用いられる。ここで絹繊維 を複合材料の強化繊維の観点から考えると, 精練は表面 処理のひとつとして捉えることができる。つまりセリシ ンの除去は繊維表面の化学的な組成を変化させる工程と なり, マトリックスとの接着性に影響を与えるものであ る。しかし, 本研究では絹繊維強化複合材料を開発する 研究の第一歩として, 精練を施していない生系を強化緎

*KATORI Shigetaka, 京都大学ベンチャー・ビジネス・ラボラトリー, **KIMURA Teruo, 京都工芸纎維大学 
維として用いることとした。図 1 に絹纎維と代表的なセ ルロース繊維の $\mathrm{S}-\mathrm{S}$ 曲線を示す。それぞれの繊維の強 度はそれほど大きな違いは認められないが，明らかに破 断伸度が異なることがわかる。セルロース繊維では約 2 〜 3\%であるのに対し，絹繊維は $20 \%$ 以上を示し，約 10 倍の伸度を有している。このような繊維の力学的性質の 違いは母材と複合化した際，成形品特性に大きな違いが 生じることを予測させ, 従来のセルロース瀻維を用いた 天然繊維複合材料とは異なる性質のものが得られること が期待される。

複合材料の強化繊維には成形工程中に受ける熱負荷に 耐え得るだけの耐熱性が求められている。一般的な FRP にはガラス繊維や炭素繊維が用いられているため,この 点はほとんど考慮する必要はないといえるが，天然繊維 の場合，耐熱性は大きな課題のひとつである。そこで成 形工程中に受ける熱負荷を想定し，絹纎維の耐熱性につ いて検討を行った。ここでは成形性がよく汎用性の高い ポリプロピレン (PP) をマトリックスとして用いるこ とを想定して熱負荷温度は $180^{\circ} \mathrm{C}$ 一定とし，時間を変化 させて熱負荷を与えたときの繊維強度の変化について検 討した。図 2 に熱負荷を与えたときの絹瀻維の $\mathrm{S}-\mathrm{S}$ 曲 線を示す．熱負荷時間が長くなるに従い，強度，破断伸

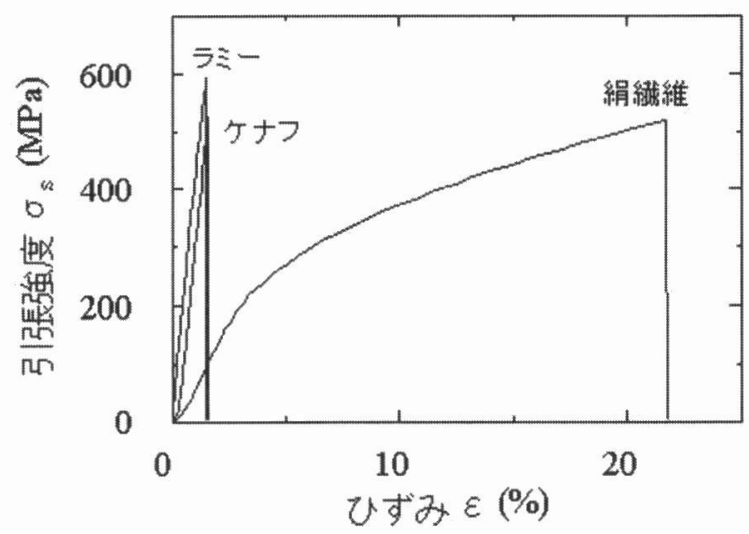

眓 1 絹繊維とセルロース繊維の引張特性

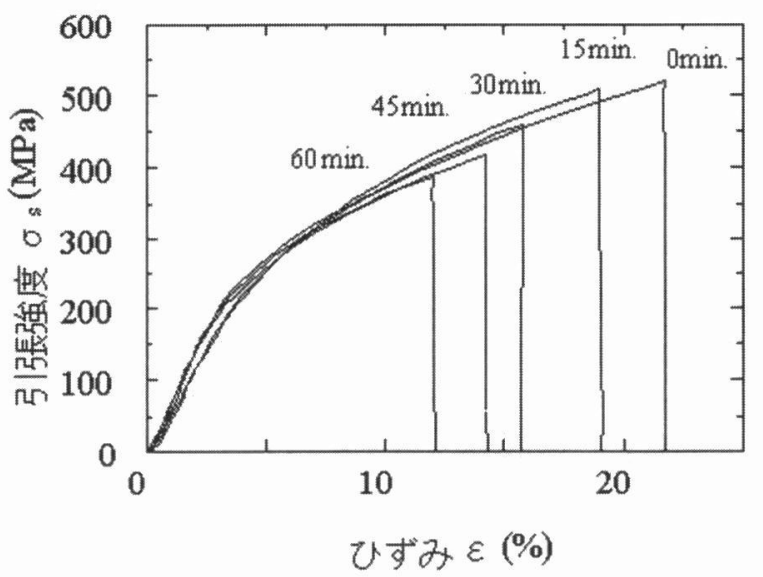

図 2 絹繊維の耐熱特性
度ともに小さくなることが明らかであるが, 熱負荷時間 60min であったとしても繊維の強度は約 $400 \mathrm{MPa}$ を有し ている。この值は小さいように見えるが，母材となる樹 脂の強度は数十 $\mathrm{MPa}$ のものが多いため一桁大きいこと となり,十分強化材としての機能を果たすと考えられる. また，同様の実験をセルロース䋊維で試みたところ，30 分間熱負荷を与えた繊維の強度は約320MPa まで低下す ることが明らかとなり，絹繊維はセルロース繊維よりも 耐熱性が高く複合材料強化材として有効であると考えら れる。

\section{3．絹繊維強化複合材料の射出成形}

複合材料の成形手法には種々のものがあるが本研究で は安定した成形品が量産できる射出成形法による成形を 試みた、マトリックスには汎用樹脂であるポリプロピレ ンを使用し, 強化繊維には精練を施していない生系（以 下絹繊維と呼ぶ）を用いた。このとき絹繊維を安定して 成形機に投入するため，あらかじめ図 3 に示すような絹 繊維含有の予備成形品を作製した. まずホットプレス機 を用いて PPペレットをフィルム状に加工し, 約 $5 \mathrm{~cm}$ 長にカットした繊維を繊維体積含有率（Vf）が10\%およ び20\%になるようにフィルムにはさみ厚み $2 \mathrm{~mm}$ のサン ドイッチ板を加熱圧縮成形した。最後に成形品を約 3 $\mathrm{mm} \times 10 \mathrm{~mm}$ の大きさにカットレフレーク状の予備成形 品を得た。作製した予備成形品を十分に乾燥させた後, 射出成形機に投入し, 複合材料の成形を行った。また, PPをマトリックスとした場合, 強化瀻維との接着性が 不十分となることが予測されるため，一般的によく用い られる無水マレイン酸変性 PP (MAPP) をバインダー剂 として Vf=10\%のものに添加し, 絹繊維との接着性に ついて検討を行った. さらにガラス䋊維強化複合材料と 比較するため同種のマトリックスからなるガラス繊維入 りポリプロピレンペレット（日本ポリケム製, NOVATEC PP HG30U）を素材とする試験片も成形した。成形品形 状はJIS K7113に準拠したものである。なお，成形には 一般的なインライン式射出成形機（東洋機械金属製 Plaster Ti-30G）を使用した。

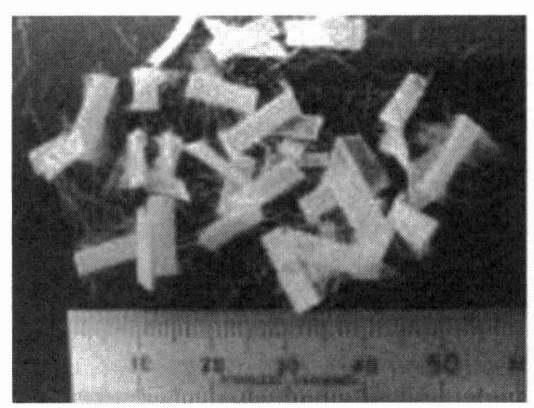

図 3 絹繊維含有予備成形品 


\section{4. 絹繊維強化複合材料の特性}

\section{1 成形品中の絹繊維の分散性}

成形品中における絹繊維の分散状態について検討を 行った。図 4 に成形品断面のSEM 観察写真を示す。図 は繊維含有率 $10 \%$ の場合についてガラス繊維複合材料の 結果とともに示したものである。ガラス緎維はフィラメ ント状の繊維が断面一様に分散している様子が観察され るが，絹繊維の場合，多くの繊維はフィラメント状に分 離することなく初期の生糸のまま存在していることがわ かる. すなわち, 生系は十数本の絹フィラメントがセリ シンによって結合されているが，成形工程中においてこ のセリシン部分の接着部はほとんどはがされることはな く，フィラメント状に分散していないことがわかる。し かし，いくらかの細い繊維も見られ一部はセリシン部分 の分離も生じていると考えられる。したがって同体積含 有率で比較するとフィラメント状に分散するガラス緎維 に比べて絹繊維では繊維部分とマトリックス部分に明確 に分離し，レジンリッチ部分が存在することになる。

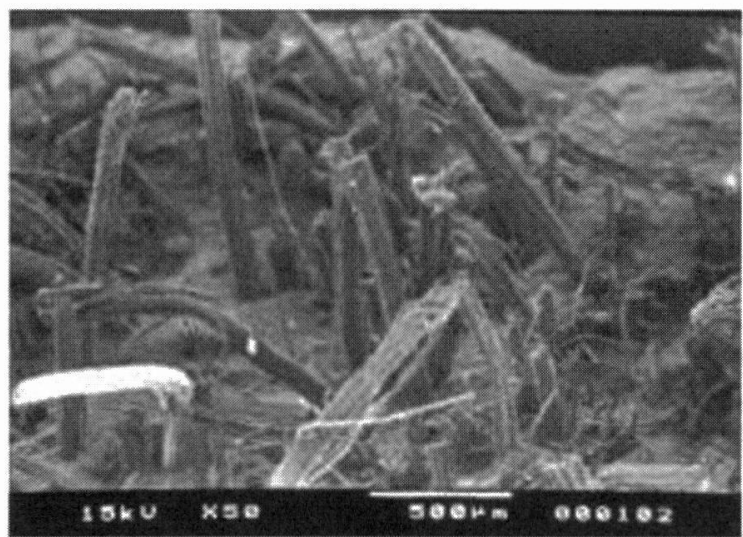

(a) 絹繊維複合材料

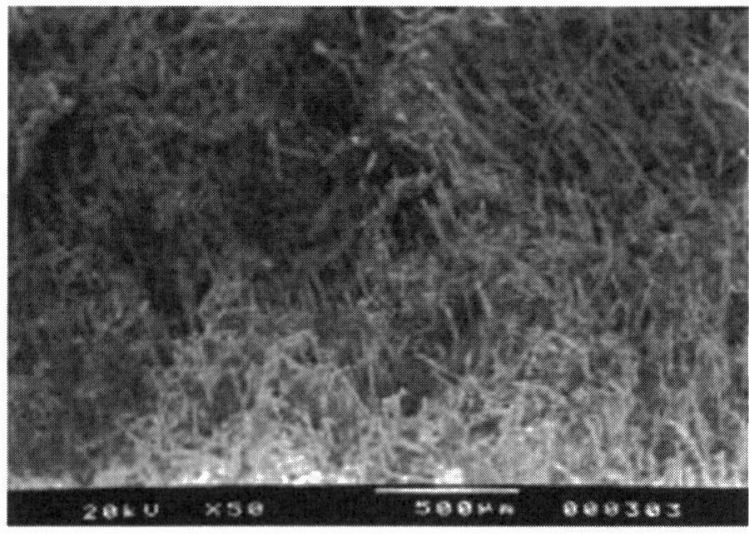

(b) ガラス繊維複合材料

図 4 成形品断面の SEM 観察

\section{2 引張特性}

図 5 は絹纎維複合材料の典型的な荷重一変位曲線を示 したものである．PPの場合，最大荷重を示した後も破 断には至らず延性的な材料であることがわかる。一方, 絹繊維を複合化させると最大荷重はPP単体よりも高 く，補強効果が得られていることがわかる。しかしなが ら, PP 単体のように大きく変形することはなく最大荷 重点で急激な破断に至っている。また，ガラス繊維複合 材料およびバインダー剤を添加した場合を見てみると MAPPの添加により破断伸びは若干小さくなるが，最大 荷重は顕著に大きくなることがわかる。これはMAPP により繊維/マトリックス界面の接着性が改善されたた めである，次にガラス繊維複合材料と比較すると最大荷 重はかなり小さいが，破断伸びは非常に大きいことがわ かる。すなわち, 絹複合材料は同体積ガラス含有率のガ ラス繊維複合材料に比べて柔軟性のある材料であるとい える。図 6 および図 7 に引張弾性率および引張強度と繊 維含有率の関係を示す. 弾性率, 強度ともに䋊維含有率 の増加とともに増加し, 補強効果が認められる。しかし ながら，ガラス繊維複合材料と比べるとその值は決して

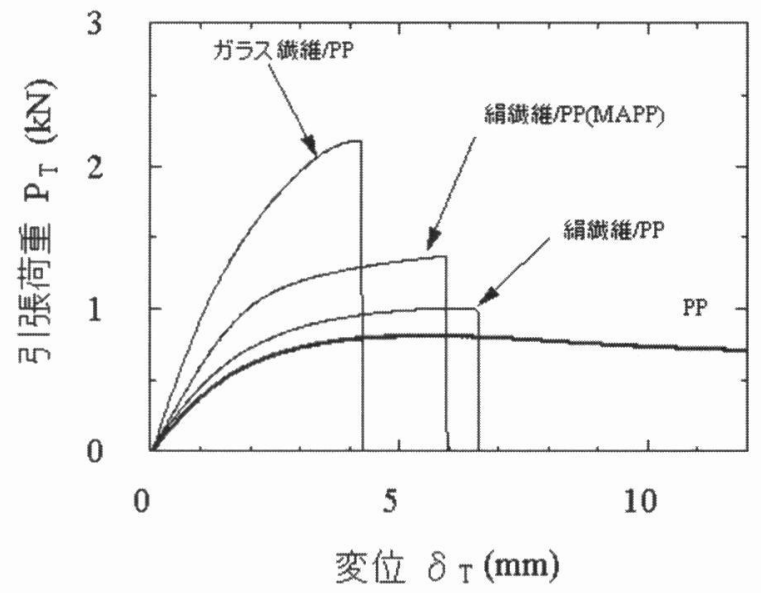

図 5 絹繊維複合材料の引張荷重一変移曲線

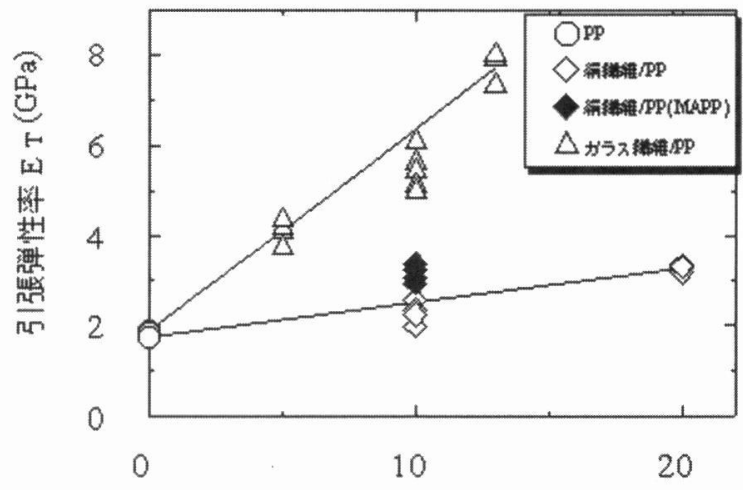

繊維体皘含有率 $V_{f}(\%)$

図 6 引張弾性率と絹綫維含有率の関係 


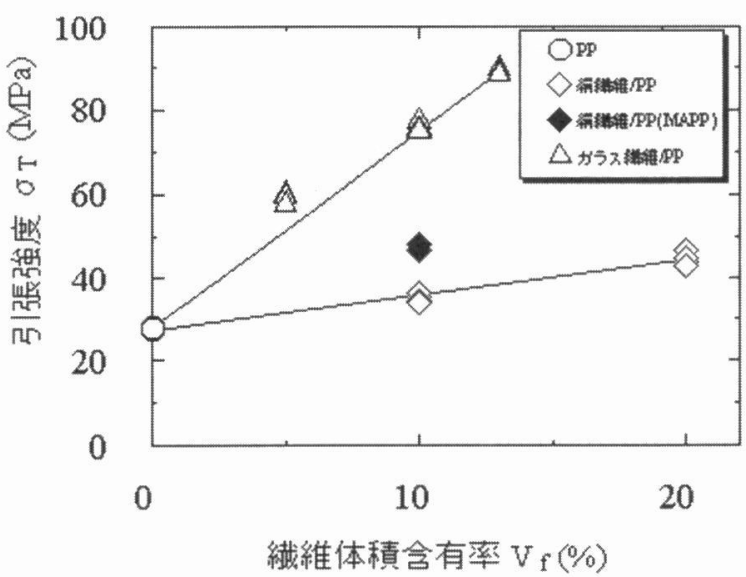

図 7 引張強度と絹繊維含有率の関係

高いものとはいい難い.このことは強化繊維であるガラ ス繊維と絹繊維の強度, 弾性率の違いが複合材料の特性 にも明確に現れたためといえる。

\section{3 曲げ特性}

絹複合材料の曲げ特性について繊維含有率 $10 \%$ の場合 を例に示す。図 8 は実験によって得られた典型的な荷重 一たわみ線図をガラス䋊維複合材料の結果とともに示し たものである。絹複合材料はPP 単体と同様に最大荷重 に達した後もガラス繊維複合材料のような急激な破断に は至らず，延性的な挙動を示していることがわかる。す なわち，引張特性と同様に絹複合材料はガラス繊維複合 材料に比べて柔軟性のある複合材料であるといえる。

表 1 は荷重一たわみ線図の初期の傾きより求めた曲げ 弾性率および最大荷重より求めた曲げ強度について示し ている.PP 単体に比べて曲げ弾性率は1.4倍, 曲げ強度 は1.2〜1.4倍の向上が得られ，絹繊維は曲げ負荷に対し ても強化材として有効であるといえる。

\section{3 衝撃特性}

四 9 は絹複合材料のアイゾット衝撃特性について示し たものである。マトリックス単体に比べて絹複合材料の 衝撃值は非常に高く, 同体積含有率のガラス繊維複合材 料と比べてみるとほぼ同程度の值を有していることがわ かる，先述の引張，曲げ試験においては，絹複合材料の 特性はガラス繊維複合材料に及ばなかったが，衝撃特性 においてはガラス繊維複合材料に匹敵する耐衝撃性を有 していることがわかる。また，セルロース繊維を用いた 射出成形品では成形工程中の熱負荷による繊維劣化の影 響などがあり，あまり高い衝撃特性は得られなかった。 このため天然繊維を用いた射出成形品においてガラス繊 維複合材料に匹敵する特性が得られたことは非常に大き な知見といえる.

また，図10は各試験片の破断の様子を示したものであ る。PP単体は 2 つに破壊していることがわかるが，絹

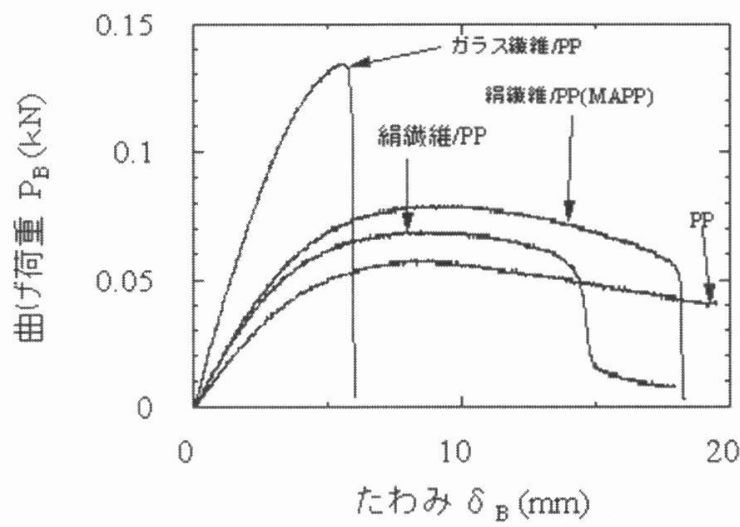

図 8 曲げ荷重一たわみ曲線

表 1 絹複合材料の曲げ特性

\begin{tabular}{|c|c|c|}
\hline & $\begin{array}{c}\text { 曲げ強度 } \sigma_{B} \\
(\mathrm{MPa})\end{array}$ & $\begin{array}{c}\text { 曲げ弾性率 } \mathrm{E}_{\mathrm{B}} \\
(\mathrm{GPa})\end{array}$ \\
\hline $\mathrm{PP}$ & 52.2 & 1.72 \\
\hline 絹繊維複合材料 & 64.3 & 2.41 \\
\hline 絹繊維複合材料(MAPP) & 72.9 & 2.46 \\
\hline ガラス繊維複合材料 & 116.3 & 4.64 \\
\hline
\end{tabular}

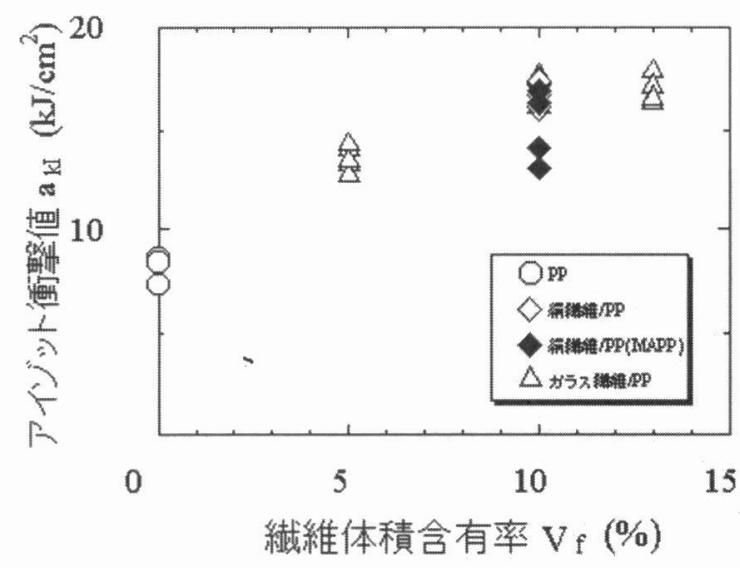

図 9 アイゾット衝撃值と繊維含有率の関係

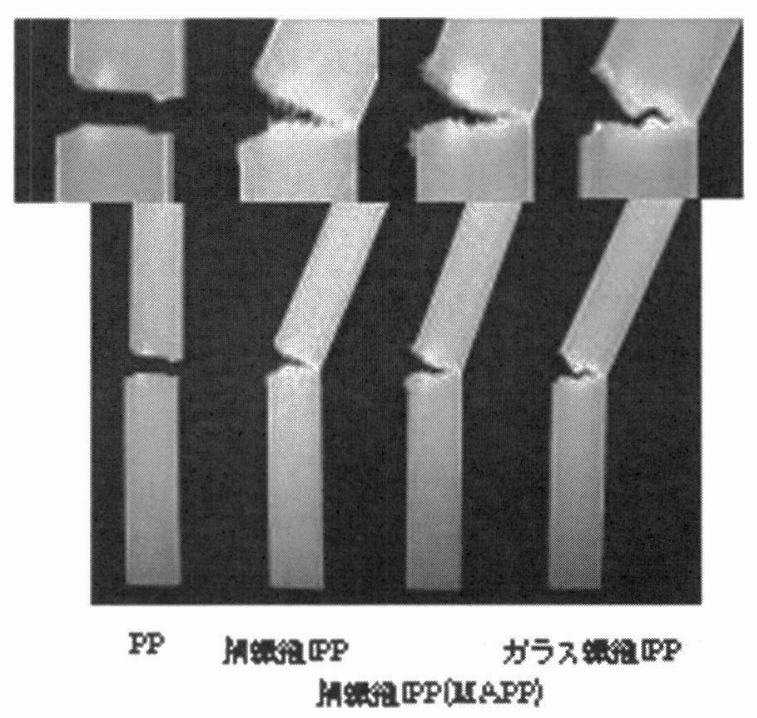

図10 アイゾット衝撃試験後の破壊様相 
複合材料は破断には至らず，纎維の変形に多くの衝撃工 ネルギーが吸収されたものと考えられる。なお，MAPP を用いた場合には瀻維の切断が見ら衝撃值は MAPP を用いない場合に比べ若干小さな值となった。

\section{5. まとめ}

天然繊維複合材料の開発の一環としてタンパク質から なる絹䋐維と沉用樹脂であるポリプロピレンを用いて複 合材料を射出成形し，成形品特性を検討した結果を以下 にまとめる。

（1）絹繊維の含有率の増大とともに強度，弾性率は向 上し, 絹瀻維は複合材料強化材として十分に使用可能て あり，またガラス繊維と比べて比重が小さいため，成形 品の軽量化に有効である.

（2）絹緎維を生系の状態で使用するとマトリックス中 への分散性が不十分であり，絹纎維を強化材として有効 利用するには精練の効果の吟味が必要である.

(3) PP と生系の接着に無水マレイン酸変性 PP の添加 が有効である。

（4）絹瀻維の複合化により，衝撃吸収に対してガラス 繊維に匹敵する効果が得られる。

\section{6. おわりに}

本研究は環境対応型素材開発の一環として天然瀻維の なかでもこれまで複合材料の強化瀻維としては検討さ れていなかったシルクに注目し研究を行ったものであ る。しかし，シルクに限らず天然に存在する材料を工業 的に利用することは単に環境への配慮という面だけでは なく，別の一面も同時に併せ持っている。すなわち，天 然材料の多くは古くから地域産業と密接に結びついてい る場合が多い。したがって，それらの材料を用いること は地域産業の活性化にも大きく結びつくものといえよう.

本研究で用いたシルクも京都の伝統産業のひとつであ り，これを複合材料の分野に用いることは伝統産業と先
端技術との融合としての側面でもある。また，諸外国に おいても楖子繊維やバナナ繊維などを用いる複合材料が あるが，それらはその地域でしか取れないものを有効利 用しようとする動きのひとつでもある，天然資源を積極 的に先端材料に応用する動きが, 単に環境問題だけでは なく地域産業の活性化とも有効に結びつき, 伝統的な産 業に新たな展開をもたらすような, より大きな発展を遂 げることを願うところである。

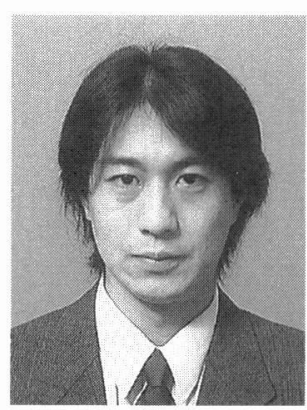

香取重尊(かとりしげたか)

平成15年, 京都工芸䋐維大学大 学院博士後期課程修了, 現在, 京 都大学ベンチャー・ビジネス・ラ ボラトリーに勤務，セルロースお よびタンパク質系の天然繊維を用 いた複合材料の開発を行うととも に, 光・電子機能をもつ有機材料 に関する研究に従事. (京都大学 VBL, =606-8501 京都市左京区吉 田本町, TEL. 075-753-7578, FAX. 075-753-7579,

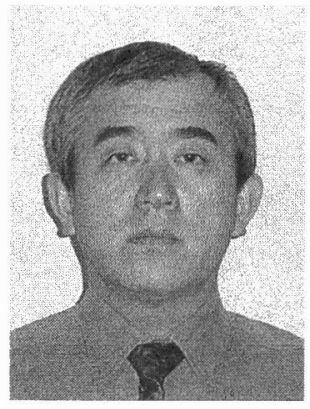

木村 照夫（きむら てるお）

昭和53年, 同志社大学大学院工 学研究科機械工学専攻博士課程後 期単位取得退学後, 福井大学工学 部機械工学科助手、助教授を経て, 現在, 京都工芸䋐維大学大学院先 端ファイブロ科学専攻教授, ファ イブロ環境工学部門を担当. (京都 工芸繊維大学大学院先端ファイブ 口科学専攻, ₹606-8585 京都市 左京区松ヶ崎御所海道町，TEL. 075 -724-7863, FAX. 075-724-7800,

\section{繊維産業に携わる研究者・技術者は日本繊維機械学会の会員に!}

日本繊維機械学会は，繊維産業（繊維製造〜アパレル〜流通）に携わる研究者・技術者の結集体として昭和 23 年 創立以来，56年にわたって産学連携を基調に絶ゆまざる活動を続けております。

また，本学会内に設置された研究会（不織布研究会, 生活環境と繊維の研究会, テクテキスタイル研究会, 繊維 リサイクル技術研究会, 織機研究委員会, 染色加工研究会, コンポジテックス研究会, 染織品と染織文化財研究会, テキスタイル科学研究会ほか）にもそれぞれの分野の方々が参加されています.

学会活動の活発化や会員の相互啓発は会員が多数であればあるほど，より高まり深くなります。会員各位におか れましてもお知り合いの方でまだ未入会の方がおられましたら，ぜひご入会をおすすめいただきますようお願い致 します. 